\title{
LA ECONOMÍA DEL CASTIGO Y EL PERDÓN EN TIEMPOS DE CERVANTES*
}

\author{
TOMÁS A. MANTECÓN MOVELLÁN \\ Universidad de Cantabria ${ }^{\mathrm{a}}$
}

\section{RESUMEN}

En la Castilla de la temprana Edad Moderna, la autoridad del monarca se ejercía en el plano de la política a imagen de la económica o arte del buen gobierno de la casa. El rey, como padre prudente de los súbditos, debía emplear el castigo y la gracia para mantener el equilibrio del cuerpo político. El ejercicio de la justicia debía culminarse con el castigo o el indulto de los delincuentes. La Sevilla en que se asentaba la corte de Monipodio, retratada por Cervantes, ofreció un sin fin de ocasiones para la práctica judicial. El estudio de los ajusticiados e indultados sevillanos de los tiempos cervantinos permite caracterizar la práctica judicial a partir de estos presupuestos y matizar la imagen represiva que nos legó Foucault en su Surveiller et punir.

Palabras clave: justicia, castigo, indulto, Sevilla, Foucault, Edad Moderna

\section{ABSTRACT}

In early modern Castile the Crown authority was played within the political arena having as a mirror the so-called economica (the art of the good government

* La investigación para la preparación de este artículo se encuadra dentro del proyecto Ciudades en conflicto: las corporaciones urbanas de Castilla entre la inestabilidad y el orden (siglos XVI-XVIII) financiado por el Ministerio de Educación y Ciencia (2003-2006). Proyecto: BHA 2003-08918.

a Departamento de Historia Moderna y Contemporánea. Facultad de Filosofía y Letras. Edificio Interfacultativo, Avenida Los Castros s/n, 39005 Santander. mantecot@unican.es 
of the household). The king, a prudent father of his subjects, should punish and sometimes pardon the criminals in order to keep the political body balanced. The criminal punishment or pardon should be the end of every lawsuit. Seville in the times of Cervantes offered lots of occasions to develop judicial practices. This article explains how justice was developed within this framework and gives a picture of Ancient Régime justice quite different to the repressive justice depicted by Foucault in his Surveiller et punir.

Keywords: justice, punishment, pardon, Seville, Foucault, early modern times JEL Classification: N43

\section{INTRODUCCIÓN}

Este año, Don Quijote cumple cuatrocientos bien llevados, y nos da ocasión para recobrar algunas de las significaciones históricas que tenía la economía o económica en la sociedad de los siglos XVı y xviı, así como la aplicación de esa semántica del «arte del buen gobierno de la casa» a las relaciones entre rey y súbditos, es decir, la política, en un plano tan axial como era el de la administración de justicia. Me interesa particularmente explicar uno de los puntos más sensibles de la justicia, como era el de la administración de la gracia del rey a través de una potestad que le era exclusiva e indelegable: el ejercicio del perdón, el indulto de criminales. Es ésta una materia importante que ha sido estudiada principalmente en sus manifestaciones jurídicas, procedimentales. En estas páginas se realiza un análisis de información referida a ajusticiados y condenados sevillanos en la época en que Miguel de Cervantes ubicó en la capital hispalense a sus personajes Rinconete y Cortadillo. Se vivía entonces el momento dorado de la historia de la ciudad andaluza, cuando las flotas de América dotaban de gran dinamismo a la actividad portuaria, y la urbe alojaba mayores magnitudes de población dentro de sus murallas, convirtiéndose, con sus más de 130.000 habitantes, en una de las ciudades más pobladas de la Europa Atlántica, sólo superada por París, en torno a los 200.000 habitantes, y con cifras por encima de Amsterdam y Londres, que rondaban los cien mil. La cuestión adquiere también un renovado interés al permitir una reflexión sobre la justicia del Antiguo Régimen y reconsiderar alguno de los planteamientos sostenidos por Foucault en su influyente Surveiller et punir, que también cumple años, treinta, desde su primera edición por Gallimard en París.

\section{EL CASTIGO SOBRE EL CUERPO DE LOS CRIMINALES}

Las páginas del Surveiller et punir se abrían con la descripción del calculado y dosificado tormento sufrido en público el 28 de marzo de 1757 por un hombre de 
cuarenta y dos años llamado Robert François Damiens, Robert le Diable, inculpado de intento de regicidio en la persona del futuro Luis xv. El dramatismo de la tortura de Damiens permitía mucho después a Michel Foucault caracterizar la justicia del Antiguo Régimen como represiva, actuando directa y rigurosamente sobre los cuerpos de los condenados más que sobre sus mentes, por oposición a otra modalidad de justicia, la que alimentó el nacimiento de las prisiones sobre las bases de la reinserción de los reos, es decir, aquella que no buscaba la destrucción de los cuerpos sino que, interviniendo en las mentes de los reos, pretendía la transformación de éstos en «cuerpos dóciles», útiles. Una severa reglamentación de la vida del recluso, el control de los horarios, la clasificación de las tareas y la administración del tiempo otorgarían utilidad a los ya «dóciles» reos. El esquema de Foucault no pretendía profundizar en el análisis de la justicia del Antiguo Régimen, pero, al contemplar esta transición de un modelo represivo a otro utilitario, caracterizaba implícitamente y de una forma excesivamente simplificada la justicia de ese «mundo que hemos perdido» cuyos rasgos estructurales más sobresalientes trazara anteriormente el historiador británico Peter Laslett (1965). Éste, sin embargo, entonces y en los ochenta, cuando ese mundo perdido era «explorado de nuevo» ${ }^{1}$, omitió un análisis de la criminalidad.

En la lectura de un proceso criminal tras otro, el historiador del crimen lee sentencias redactadas en la época preindustrial que refieren toda suerte de castigos torturantes que ofenden nuestros parámetros y valores contemporáneos tanto como conmueve la descripción del desmembramiento de los tejidos y articulaciones de Damiens el terrible 28 de marzo parisino de 1757. La justicia del Antiguo Régimen ahorcaba, decapitaba, descuartizaba, asaeteaba, atormentaba, mutilaba y quemaba criminales. En la Castilla de la temprana Edad Moderna, los alcaldes de la Santa Hermandad flechaban a los bandidos que eran juzgados y condenados por sus jueces. Estas espectaculares ejecuciones públicas tenían lugar no en las plazas de las ciudades, sino en los mismos caminos que habían asistido a las fechorías de los salteadores. Algunos muchachos, incluso «hijos de buenos padres», a los que «las malas compañías lo trajeron a esto», conocieron una muerte de esta naturaleza. Así murió en 1594 un muchacho llamado Pedro Martín, alias Salcedo, en el término de Mairena, en el camino entre Granada y Sevilla. Otros, como Francisco García, vecino de Brenes, y Alberto de Robleda, natural de Antequera, perdieron sus manos derechas después de ser ahorcados en Sevilla el 19 de febrero de 1596. Habían sido acusados de capeadores y haber provocado una muerte. Sus manos, una vez cortadas, fueron colocadas en la Calle del Naranjuelo, justamente en el lugar donde estos soldados de galeras habían tenido un encuentro y riña con un criado del deán de Sevilla. Otros tres o cuatro compañeros de Francisco y Alberto que no fueron apresados lograron eludir el escarnio público, la pena capital y la mutilación ritual².

\footnotetext{
${ }^{1}$ Laslett (1983).

${ }^{2}$ León (1628), ff. 320, 343-343 $\mathrm{v}^{0}$.
} 
Poco más de un año después, sufrió un castigo similar una mujer llamada Constanza Pérez, ahorcada en Sevilla por ladrona famosa el 21 de marzo de 15973. Para juzgar y ejecutar a esta mujer hubo conflicto de competencias entre la Santa Hermandad y el corregidor sevillano. Los alcaldes de la Hermandad la tenían sentenciada de muerte «en el campo y con saetas», pero la audiencia de Sevilla la condenó a horca. Se produjo una fricción entre las dos jurisdicciones. Al fin, acordaron que la ejecutaran los alcaldes de la audiencia «y así se hizo, saliendo de la cárcel de la Hermandad con su pendón verde y sus cuadrilleros delante, con sus ballestas como suelen, pero no la asaetearon sino la ahorcaron en la Plaza de San Francisco». La mutilación de Constanza Pérez seguía el mismo patrón que la de Francisco García y Alberto de Robleda, pero también informa sobre la necesidad de reflejar la significación de la acción de la justicia. Los ballesteros de la Santa Hermandad no podían dejar de estar presentes. El castigo de Constanza debía llevar ese sello. La escenografía era un componente fundamental del castigo.

No sólo las manos podían ser separadas de los cuerpos de algunos condenados dentro del ritual que seguían sus castigos y ejecuciones. Los «cuartos» y las cabezas de los criminales se podían también segregar mutilando o fragmentando los cuerpos de los criminales. Una vez practicado este ritual, se podían y debían colocar esas fracciones anatómicas en lugares bien visibles, allí donde los delincuentes habían cometido sus actos criminales. De este modo se enmarcaba el espacio del delito, se recordaba su territorialidad y la del castigo que había provocado, actuando este instrumento como elemento visible que pretendía lograr la disuasión de posibles ulteriores acciones criminales. A Damián de Carmona, ahorcado el 29 de julio de 1595 en la capital hispalense, «le quitaron la cabeza y la pusieron en una jaula encima de la puerta del Almenilla porque mató a otro hombre». Carmona, que había cometido homicidio en una pendencia urbana, formaba parte de un grupo de alborotadores, «valentones» que se reunían en un lugar llamado La Ventilla, cerca de La Barqueta. Fue capturado por una cuadrilla formada por el Conde de Priego «y más de cien hombres». La Ventilla fue derribada y sembrada de sal, aunque «ya otra vez, en tiempos pasados, dicen los viejos de Sevilla, que estuvo derribada por mandato de la justicia, porque siempre aquel lugar ha sido cueva de ladrones y de gente inquieta, rufianes y malas mujeres». Años atrás, en 1588, otro hombre, Andrés Martí fue ahorcado y descuartizado «por una alevosía y traición notable hecha en Villa Martín, doce leguas de Sevilla». «Llevaron la cabeza y el cuarto de este hombre a poner en Villa Martín, y los demás cuartos acá en los caminos de Sevilla». Entre él y su víctima había habido discusión. «Metiéronlos en paz e hiciéronlos amigos», pero Andrés quedó deseoso de venganza y le tendió una trampa, logrando consumar la muerte de su adversario.

${ }^{3}$ León (1628), ff. $348 v^{0}$-349. 
Menos calculada, pero con igual resultado al descrito, fue la fechoría cometida por Diego de Arce, hijo del bordador mayor del arzobispado. Fue ahorcado y descuartizado el 15 de octubre de 1588 «por capeador, y porque mató a uno por quitarle la capa». Las malas compañías juveniles llevaron a este muchacho a la horca y descuartizamiento en las callejas detrás de Santa María, «donde había muerto al otro» ${ }^{4}$. El caso del mulato Benito Ruiz, ahorcado y «hecho cuartos» el 6 de febrero de 1595 «porque había hecho fuerza a muchas mujeres en el campo y por salteador» tenía otras connotaciones. Había sido sentenciado en Valencina del Alcor en el Aljarafe a galeras. Apeló y lo llevaron a la cárcel de la audiencia de Sevilla, donde su causa «estúvose durmiendo» tres años, en los cuales gozó de libertad por la clemencia del alcaide de la cárcel. La causa se siguió y fue sentenciado a la horca, pero suplicó perdón y en medio, gozando de «soltura», se le fueron acumulando más delitos del mismo jaez de los que anteriormente había cometido, por lo que en definitiva lo sentenciaron a ahorcar y hacer cuartos 5 . La dureza de estas ejecuciones cortaba trayectorias criminales con difícil vuelta atrás o en aquellos casos en que el delito manifestara una evidente alevosía o contumacia por parte del criminal.

Lo mismo que a Damián Carmona, Andrés Martí, el mulato Benito Ruiz o Diego de Arce ocurrió años después a Francisco García, Manotas, ahorcado «por facineroso» el 7 de abril de 1611, le cortaron la cabeza y la pusieron en una jaula a la puerta de La Macarena de Sevilla, donde lo habían ahorcado. «Este era de los valentones de la feria y llamáronle Manotas porque las tenía muy grandes para hacer mil insultos y travesuras». Dos años después, el 17 de septiembre de 1613, otro reo, un joven esclavo negro de dieciocho años, fue ahorcado y su cabeza cortada y colocada en una torre cerca de la taberna en que él había discutido con la tabernera y puesto fin a su vida «de dos ladrillazos», justo antes de salir a la calle y tratar de forzar a otra mujer. Tres años más tarde, el 26 de abril de 1616, fue ahorcado por diversos crímenes de heridas, muertes y salteamientos en los caminos un rufián llamado Pascual Carretero, que ya había conocido una sentencia previa de azotes y ocho años en galeras, de los que sólo cumplió ocho meses, para después volver a vivir como bandido. Prendido en Murcia y remitido a Sevilla, su cabeza acabó en una jaula colocada en la puerta de Carmona ${ }^{6}$. Ajusticiamientos de este tipo eran eventualmente conocidos en una gran ciudad con la actividad económica y portuaria de Sevilla, que ejecutaba entre veinticinco y treinta criminales por año ${ }^{7}$. El ejemplo hispalense, aunque notable dentro del encuadre

\footnotetext{
${ }^{4}$ León (1628), ff. 309-309 $v^{0}$.

${ }^{5}$ León (1628), ff. 329-329 vo.

${ }^{6}$ León (1628), ff. $362 \mathrm{v}^{\mathrm{o}}, 363 \mathrm{v}^{\mathrm{o}}-364,383-384$.

${ }^{7}$ Es la cifra que emerge de los años entre 1580 y 1586, en que el padre Pedro de León se aplicó con más intensidad en la confesión y asistencia de los ajusticiados en la capital hispalense.
} 
castellano, no era la excepción dentro de su contexto europeo. Dentro de ese marco era incluso relativamente modesto, si se compara con los promedios de otras ciudades portuarias atlánticas en sus momentos de mayor esplendor económico y demográfico. Amsterdam, una de las que menos ejecuciones registra, conoció casi cuatro por año en los cien años que siguieron a 1650. En la mitad de los casos, los cuerpos de los ajusticiados fueron descuartizados y colocados en el puerto, al otro lado de la bahía, pero bien visibles para los navíos que arribaban ${ }^{8}$.

Como en Sevilla y Amsterdam en sus momentos dorados, a lo largo de toda la Edad Moderna, todos los años, en varias fechas bien señaladas o bien improvisadas por los tribunales, los jueces de toda Europa condenaban un buen número de personas a ser ejecutadas o castigadas de estas o similares suertes. Particularmente, las ciudades eran los teatros en que estas exhibiciones públicas del dolor se expresaban con regularidad, ofreciendo una oportunidad para mostrar el arrepentimiento del reo y la penitencia por la que redimía sus culpas, convirtiendo cada rito relacionado con el castigo en una ocasión instructiva para los asistentes. También es cierto que las sensibilidades de las gentes hacia la escenografía de los castigos cambiaron muy notablemente en las ciudades occidentales a lo largo de los siglos de la Edad Moderna. Lo que se aplaudía y celebraba con tono festivo en el siglo xV o durante la mayor parte de los siglos XVI y XVII, sin embargo, podía posteriormente acabar resultando un espectáculo incómodo, a veces incluso molesto, desagradable y quizá inútil e innecesario.

En Amsterdam, por ejemplo, en las últimas décadas del siglo XVII, los burgueses, embajadores, cónsules y patricios urbanos que vivían en los alrededores del dam reconocían y expresaban su desagrado por los gritos que proferían los azotados y las molestias de todo tipo que les causaban las ejecuciones públicas en las cercanías de sus residencias y habitaciones ${ }^{9}$. La fiesta que rodeaba los castigos comenzaba a perturbar la quietud de las élites urbanas y, quizá, también su mayor sensibilización hacia el dolor de los penados ayudaba a alimentar sus comentarios. En realidad no se trataba de una crítica hacia el castigo corporal en sí, sino hacia su dimensión pública, como festival urbano, y, sobre todo, hacia la cercanía del emplazamiento urbano de este evento con sus propias residencias y centros de sociabilidad. Eso era lo que realmente molestaba a los patricios urbanos y cónsules comerciales de la próspera ciudad holandesa. Este tipo de sensibilidad, sin embargo, no había sido desarrollada en la capital neerlandesa y probablemente tampoco en otras ciudades de la Europa atlántica en fechas más tempranas.

La sensibilización de los patricios de la capital holandesa hacia las dimensiones públicas de los castigos corporales no es, a pesar de todo, estrictamente

\footnotetext{
${ }^{8}$ Spierenburg (1991a), p. 209.

${ }^{9}$ Spierenburg (1991b).
} 
generalizable al conjunto de los entornos urbanos europeos, incluso en fechas que rebasaban la barrera de 1700. En Londres, por ejemplo, es un hecho que las multitudes acompañaban los carros que conducían a los condenados, con frecuencia cargados de alcohol y jaleados por la multitud, al patíbulo de Tyburn en el siglo XVIII. Los días de ejecución eran en la capital británica un gran evento en que participaban gentes de todos rangos hasta cifras que rebasaban incluso las tres decenas de millar de almas ${ }^{10}$. Después de la ejecución, las mismas masas urbanas se convertían en consumidoras de una literatura popular que alimentaba la construcción de arquetipos criminales sobre la base de los last dying speeches de los condenados ${ }^{11}$. Bernard Mandeville (1725), espectador directo de muchos de estos episodios, fue un crítico contemporáneo de lo que era un auténtico fenómeno de masas.

El ejemplo sevillano también ofrece numerosas pruebas concretas de la gran conmoción social que suponían las ejecuciones públicas en la temprana Edad Moderna. En la Castilla urbana, estos eventos eran entonces muy del gusto de las multitudes. En la Sevilla de Rinconete y Cortadillo, en su etapa dorada y cuando más efectivamente debió funcionar la horca, de acuerdo con los registros anuales más exhaustivos del apéndice de ajusticiados confeccionado por el padre Pedro de León en $1628^{12}$, la proporción anual de ejecutados por cada 100.000 habitantes era de 21. En esas fechas, la capital británica, dando por buenas las estadísticas dispensadas sobre esa etapa de la historia de la city en la época victoriana por el editor y anticuario J. C. Jeaffreson ${ }^{13}$, la proporción de ajusticiados por cada 100.000 habitantes rondaba los 60. Amsterdam conocería tasas mucho menores -entre una y dos ejecuciones anuales por cada 100.000 habitantes- para el periodo $1650-1750^{14}$. La capital holandesa era ya el auténtico corazón del Randstad, la red urbana más conectada del país. La movilidad de inmigrantes tanto holandeses como alemanes y franceses era notable ${ }^{15}$. No obstante, el crecimiento tanto de la ciudad como de los problemas de orden público debió suponer un reto para la justicia y policía urbana.

En Londres ocurrió algo diferente. En los momentos en que la capital británica vivía una intensa etapa expansiva, en las primeras dos décadas del siglo XVIII, y

\footnotetext{
${ }^{10}$ Sharpe (2005), p. 85.

${ }^{11}$ Sharpe (1985), pp. 144-167.

12 León (1628), apéndice I

${ }^{13}$ Sharpe (2005), pp. 89.

14 La población de Amsterdam debió evolucionar desde los 30.000 habitantes aproximadamente de 1578 hasta los 250.000 de mediados del siglo xVIII, contando con unos 100.000 hacia 1600 , que se duplicaron con creces en los setenta y cinco años siguientes: unos 206.000 en 1675. Aceptando como promedio del periodo 1650-1750 una cifra en torno a los 228.000 habitantes, las 309 ejecuciones que reconoce Pieter Spierenburg (1991a, p. 229) para esa misma cronología arrojarían una cifra de entre tres y cuatro ejecuciones por año, lo que vendría a suponer alrededor 1,5 por cada 100.000 habitantes.
} 
cuando la justicia londinense se empleó con más severidad, antes de la Transportation Act de 1718 que habilitó la alternativa de la deportación a Virginia o Maryland en lugar de la ejecución de la pena capital, la tasa de ajusticiados públicamente no debió ser menor a la mencionada para etapas precedentes, aunque la ciudad contaba ya con una población de alrededor del medio millón de almas ${ }^{16}$. La alternativa de las deportaciones debió hacer más fácil a los jueces británicos sentenciar los casos más graves y poder combatir la importante criminalidad urbana en un contexto de crecimiento urbano sin precedentes como fue el del siglo XviII ${ }^{17}$, que disparó la criminalidad urbana hasta el punto de conmocionar a observadores tan cualificados como Daniel Defoe (1728) y Henry Fielding (1751), promotores de reformas tendentes a reducir la impronta de la delincuencia, la prostitución y el crimen organizado en las calles de la próspera capital.

Como se ve, en la época de Cervantes las justicias sevillanas aplicaban similares procedimientos a los que conocían en el siglo xvir otras ciudades de la Europa Occidental y que llevaban, como se ha visto, a exhibir fragmentos de abdomen, brazos, piernas o cabezas en picas en lugares bien visibles. Las piezas, clavadas en promontorios dispuestos tanto a la entrada del puerto holandés como ante las puertas de la muralla de la capital hispalense, mostraban el brazo más riguroso de la justicia. Con la muerte de algunos reos, con la escenografía de su arrepentimiento, penitencia y castigo ni acababa, ni podía fenecer todo el problema. El evento y la severidad de la justicia debían permanecer y actuar en la memoria de las gentes. De otro modo, su función disciplinaria, es decir, punitiva y al tiempo instructiva, quedaría minorada, y buena parte del ritual desplegado habría sido innecesario, inútil. Las comitivas de criminales hacia las plazas públicas y lugares de ejecución estaban cuidadosamente organizadas para lograr tal efecto.

El mismo año en que la Armada de Felipe II fracasaba en Inglaterra y perjudicaba la autoestima de las tropas españolas en el exterior, en Sevilla era ajusticiado el nieto de un meritorio oficial que había protagonizado conquistas militares en el Norte de África en tiempos de los Reyes Católicos. Así, el melillense Francisco de Vera no pudo servirse de su privilegio de hidalgo para eludir que le achacaran alevosía en una muerte que protagonizó. De este modo, el 25 de febrero salió en una comitiva de penados acompañado por tres salteadores de caminos que, al igual que otro, morisco, y dos compinches, fueron ahorcados y descuartizados. Delante de este grupo habían pasado otros seis o siete azotados que eran condenados a ocho años de galeras por fraudes y argucias delictivas. «Tras toda esta

${ }^{15}$ Sobre estos particulares me remito a las investigaciones de Spierenburg (1998a), pp. 355-359.

${ }^{16}$ Peter Linebaugh (1993, capítulo 3) ha realizado un exhaustivo análisis sociológico de los condenados a partir de una muestra de 1.242 ajusticiados en Tyburn entre 1703 y 1772, pero esta cifra no es la población total de ejecutados en la capital británica en ese interesante periodo. 
procesión iba María Ana de Sotomayor, la mujer del bañero de junto a San Juan de la Palma, para quemarla junto con su esclavo Jerónimo, etc. a quien iban atenazando encima de un carretón». Al lado de éste, el confesor jesuita que «iba limpiando y regalando las llagas que le hacían las tenazas ardiendo; y a la misma puerta del baño le cortaron la mano derecha; y después de ahorcados los cuatro en la plaza de San Francisco, fuimos con los dos, ama y esclavo, a la chamiza, adonde los quemaron». Según el misionero ${ }^{18}$,

«[...] todos murieron como buenos cristianos, pero lo que más me espantó fue la paciencia del Jerónimo, que ni las tenazas, ni el cortar la mano, jamás hizo el menor sentimiento del mundo, sino como si se hiciera aquello en algún palo, sino solamente: Sea por amor de Dios, más merecía yo. Y cuando le decía al verdugo que no le lastimase tanto con el fuego de las tenazas, decía el Jerónimo: Déjelo, padre, que hace su oficio y todo esto no es nada para lo que yo merezco. Y cuando yo le iba a apretar las llagas con mi pañuelo, me decía: Déjelo, padre, que no es menester tanto regalo para quien merecía estar en el Infierno o con otras llagas mayores para siempre; y esto se ha de acabar presto. Nuestro Señor Jesucristo padeció muchos males por mí sin culpa ninguna y yo tengo muchísimas de que quisiera hacer muy grande penitencia.»

Como demuestra el relato del jesuita sobre esta comitiva y la disposición de ánimo de la esposa adúltera y su amante esclavo, la actitud de los penados era un componente esencial de la escenografía del castigo, y reforzaba el carácter disciplinario buscado por la autoridad judicial y la edificación moral que pretendían los predicadores. La prevención del delito exigía de este modo toda una teatralización del castigo corporal que podía tener también aparejada una penitencia espiritual, tal como trataba de describir el misionero. La dramatización pública era tan importante que los condenados que falleciesen en prisión debían también formar parte del protocolo de ajusticiamiento. Eso explica por qué, cuando el 16 de agosto de 1579 se colocó la soga al cuello de un administrador de rentas reales en Sevilla, se proclamó también el nombre de otro que debía acompañarlo ese día en la horca y que «por aver muerto en la cárcel no se manifestaba allí su cadáver» ${ }^{19}$. Ese protocolo no fue del gusto de todos los oficiales de la justicia. El comisionado que había juzgado a los reos entendía que eso no era suficiente. Pretendía llevar allí el cuerpo inerte y colgarlo, físicamente, junto a su cómplice.

\footnotetext{
${ }^{17}$ Se ha calculado que unos 36.000 británicos fueron deportados a las colonias norteamericanas desde el Transportation Act hasta la Independencia, lo que hacía una tasa anual de 620, de los que un 16 por cien eran de origen irlandés. Sharpe (2005), pp. 90.

${ }^{18}$ León (1628), ff. 300-305 vo

${ }^{19}$ León (1628), ff. 251-254.
} 
En la Sevilla de fines del siglo xvı y principios del xvII, los más de veinticinco penados que eran ejecutados cada año componían un contingente humano que se integraba en la misteriosa corte de Monipodio en que comparecieron Rinconete y Cortadillo después de tomar contacto con la capital andaluza ${ }^{20}$. Algunos de esos penados habían sufrido torturas corporales ya antes de llegar a demostrarse su culpa. En estos momentos dorados de la historia sevillana, con un esplendor demográfico y económico que decaería después de la segunda década del siglo xviI, cada año era quemado algún hombre por pecado nefando o bestialismo. El fuego purificaba cuerpo y alma, ambos mancillados por el pecado y delito de sodomía. Aunque los condenados por sodomía eran ahogados antes de que su cuerpo fuera devorado por las llamas hasta hacerse ceniza, no eludían la hoguera. No podía ser de otro modo, pues «si no es con el fuego i hechos poluos y ceniças no ay enmendarse, o por milagro». Sin embargo, el castigo era ineludible, tratándose de un comportamiento no sólo pecaminoso y delictivo sino «indigno», contra la naturaleza y la voluntad de Dios, por lo que éste podía «dar hambre y pestilencia y otros tormentos en la tierra ${ }^{21}$.

A pesar de todo, hasta 1630, fecha en que en Sevilla cada año era quemado algún hombre por pecado nefando, sólo un quinto de los sentenciados por sodomía en los tribunales inquisitoriales era relajado a la justicia secular para su ajusticiamiento, y prácticamente ninguno lo fue con posterioridad a esa fecha ${ }^{22}$. Las llamas también se convertían en instrumento para la purificación de las ofensas de los herejes, aunque este punto debía ser aclarado, y a tal efecto se contaba con tribunales especializados, como es bien sabido. El ejemplo de Jaime Bolen, escocés de nación y quemado en Sevilla en 1594, da idea de hasta dónde debían llegar las cosas y la contumacia para recurrir a un arbitrio tan drástico. También informa, sin embargo, de que el infortunio, el carácter o temperamento del sujeto y las circunstancias y entorno social en que se moviera podían desempeñar un papel decisivo para que el final fuera la pena capital o uno totalmente distinto.

Bolen era un hombre de carácter muy duro. Durante sus periodos de encarcelamiento protagonizó escenas violentas, tras ser apresado y juzgado como hereje. En un primer momento se mostró convertido al catolicismo y fue sacado en un auto de fe, eludiendo la hoguera. Cuando se le detuvo la primera vez y fue atendido en prisión por varios jesuitas, parecía haberse convertido de buena fe, a pesar de que antes hablara de forma incomprensible y blasfemara a gritos en la cárcel, donde «estaba como un salvaje», «y daba unos saltos con todas aquellas prisiones que tenían, que llegaba con la cabeza al techo del aposento», pues con él «no se podía discutir porque era idiotísimo, tosco y bruto». Reducido por los conse-

\footnotetext{
${ }^{20}$ Cervantes (1997).

${ }^{21}$ León (1628), ff. $281 \mathrm{v}^{\mathrm{o}}-282$.

${ }^{22}$ Carrasco (1985), pp. 85-88.
} 
jos de los misioneros, parecía haberse cambiado, «se le puso un rostro sereno y alegre, manso, humilde y blando como una seda». Pero a los pocos días «quiso matar al alcaide del Castillo, y lo mordió en una mano, y lo dejó lisiado; y no cuantas otras maldades dicen que cometió dentro de la misma cárcel». Tres años después, reincidiendo en su credo, «quemáronlo vivo; fueron con él padres agustinos». En este caso, a la herejía contumaz se añadían las características de una difícil personalidad. El castigo parecía tan arrebatado como el propio personaje, aunque, dada la naturaleza de los castigos, qué menos cabía que la opción de arrebatarse.

Las principales críticas contra la aplicación del castigo corporal emergieron en la segunda mitad del siglo XVIII y principalmente se concentraron en la aplicación de la tortura en la fase de prueba de los procesos. Los textos de Forner $^{23}$ y Lardizábal y Uribe ${ }^{24}$ no dejaban dudas al respecto, y se integraban dentro de un debate europeo que tuvo en esos momentos una gran intensidad, aunque algunas sensibilidades sociales ya se hubieran manifestado con anterioridad en el Occidente $^{25}$. Sin embargo, la sensibilización hacia el excesivo o desmedido uso de la tortura era patente ya en algunos castellanos de épocas anteriores. Pedro de León denunciaba en los años veinte del siglo xviı que, en 1615, los salteadores, allanadores y ladrones famosos de casas y templos Alonso Roldán y el portugués Juan Fernández, asaeteados el 7 de abril, habían llegado en muy malas condiciones a la ejecución de su sentencia. Roldán, cuando salía para ser conducido a su ejecución «salió de la cárcel tan malo del tormento que le había dado y de no haber tenido cuidado de curarlo, aunque lo dije y requerí varias veces a así a los alcaldes de la Hermandad como a los demás carceleros; pero no se hizo sino una o dos vezes». Comentaba entonces que «era tanto el hedor que salía de los brazos atormentados que me causaba desmayo». El condenado «íbase cayendo del jumento y al fin para que no se diese consigo un batacazo en esas calles, se hubo de subir uno de los cuadrilleros a las ancas para irlo teniendo». Murió en el camino, y el jesuita condenaba la crueldad de los alcaldes de la Hermandad, cuya actitud difería al juicio de Dios.

La gavilla de Alonso Roldán llevaba cinco años robando en domicilios, iglesias, monasterios de monjas de Sevilla y caminos en los contornos de la ciudad. Un miembro de la cuadrilla, Hernando de Gálvez, también conocido como Hernando de Morales, fue asaeteado veintiún días después por el mismo motivo. Al parecer, una vez apresado y justo cuando le iban a aplicar el tormento, Gálvez enseñó sus brazos para que se vieran las huellas de todas las torturas que había conocido sin que has-

\footnotetext{
${ }^{23}$ Forner (1990), pp. 172-175 y 181-183.

${ }^{24}$ Lardizábal y Uribe (1782).

25 Spierenburg (1991a, pp. 205-213) ha mostrado estos dos fenómenos a partir del caso holandés.
} 
ta ese momento se le hubiera logrado arrancar confesión alguna. En esta última ocasión, habiendo sido reconocido ya por sus compañeros, admitió su culpa y se evitó una nueva penitencia previa a la muerte. Todas estas cuadrillas de bandidos, allanadores y, en general, ladrones urbanos necesitaban contar con una red de distribuidores que sirvieran de puente entre sus actividades delictivas y el mercado. En estas tareas destacaba la aportación femenina. La «cuestión de tormento» era un instrumento en manos de los jueces para lograr confesiones complicadas y la denuncia de cómplices, lo que podía resultar esencial en casos de homicidio, bandidaje, falsificación de moneda y, en general, todas formas de crimen organizado.

La aplicación del tormento alcanzaba también a las mujeres, con los mismos fines y aplicaciones que en el caso de los hombres. Después de conocer numerosos casos de tormento aplicado a reclusos de las cárceles sevillanas, Pedro de León consideraba que la resistencia femenina a confesar en aplicación de tortura era mayor que la del varón. Según él, «de veinte mujeres a quien se da tormento las dieciocho no confiesan el delito». La razón de esta mayor resistencia estaba en «que si ellas se dejan desnudar hasta medio cuerpo para darles tormento, como se suele, y no confiesan, no hay peligro de que ellas hayan de confesar, porque en sufriendo lo que es más para ellas, que es el dejarse desnudar, sufrirán lo menos $»^{26}$. Obviamente, con los datos disponibles no es posible comprobar empíricamente esta observación moral del jesuita.

Uno de los riesgos más evidentes del tormento era la posibilidad de inducción al error judicial, habida cuenta de que el dolor podía orientar la confesión del torturado. Ése era otro de los riesgos que ya percibía Pedro de León a principios del siglo XVII, aunque sus formulaciones tienen un interés añadido por la lectura que hacía el jesuita del error a que podía inducir la tortura. Lardizábal (1782) y Forner (1990) coincidían en la crítica a un procedimiento que entendían era una aplicación anticipada de una pena física, lo que se hacía injusto en el caso de un acusado inocente. También expresaron sus dudas sobre la veracidad que debía atribuirse a los testimonios arrancados mediante tortura. Lo ocurrido a Juan Rodríguez, Francisco Díaz (alias Pedro Díaz) y Pedro Martín, ahorcados y descuartizados en Sevilla el 9 de septiembre de 1593, serviría para apuntalar las tesis reformistas de Forner. Los dos primeros eran inocentes de la culpa que se les imputaba de asaltar en el camino junto a otros hombres y provocar la muerte de un transeúnte; sin embargo, confesaron haberlo hecho, «por temer del tormento». La verdad es que ni siquiera conocían al tercer inculpado, que sí que era, efectivamente, uno de los auténticos asaltantes. Lo único que les relacionaba era que los habían prendido «estando comiendo acaso juntos en el bodegón, como suelen muchos de diferentes impresiones y tratos» ${ }^{27}$.

\footnotetext{
${ }^{26}$ En 1616, una mujer, distribuidora de objetos robados de la cuadrilla de Pedro Guerra, manifestó una resistencia inusitada. León (1628), ff. 387-387 vo .

${ }^{27}$ León (1628), ff. 313-316.
} 
Incluso en episodios como éstos, de incuestionable inducción al error por aplicación de la tortura, la justificación teórica alimentaba los razonamientos conservacionistas de tratadistas y moralistas castellanos de la temprana Edad Moderna. Así, por ejemplo, el padre Pedro de León, conocedor en primera persona de situaciones de esta naturaleza, refiriéndose al ahorcamiento y descuartizamiento de dos hombres llamados Juan Sánchez y Antón Jiménez en la Sevilla de 1602, explicaba que, aunque ellos, recibiendo la cuestión de tormento, confesaron ser salteadores de caminos y haber protagonizado asaltos y allanamientos que en realidad había cometido una cuadrilla de moriscos, explicaba que en este y otros ejemplos «se echa de ver el orden admirable de la justicia de Dios, que algunas veces quiere que paguen lo que deben con ocasión de lo que no deben, rodeando las cosas de manera que sean acusados de lo que no hicieron para que paguen lo que habían hecho». La muerte del mulato Andrés, esclavo de un gentilhombre sevillano, en 1604, parecía más a propósito para aclarar el razonamiento del jesuita.

Andrés fue ahorcado porque se le inculpó de haber entrado a robar en una Casa de Beatas y, habiéndose levantado una de las mujeres y echándole mano a la petrina, él, «para desasirse de ella le dio una herida en la cabeza y otra desde lo alto de la ceja hasta la mitad del carrillo derecho». Siendo reconocido por la beata herida -aunque lo había visto en la oscuridad-, el esclavo confesó estos delitos en el potro. La tortura le había hecho confesar un crimen que no había cometido. Aunque luego se desdijo, fue ajusticiado, aun «diciendo lo mismo y que otras cosas había hecho él por donde merecía la muerte, pero no aquello». La actitud del inculpado «con mucha duda dejó a algunas personas de que no había confesado verdad, pareciéndoles que lo que había dicho en el tormento lo era y no lo que en la horca»; sin embargo, no parecía que la realidad fuera ésa sino la descrita por Pedro de León: «yo más me atengo a lo postrero [que declaró] para morir, supuesto que ya sabía con certeza que así como así había de morir». Este ejemplo debió afirmar al jesuita en sus razonamientos, puesto que, cuando el 13 de diciembre de 1609 fueron ajusticiados seis hombres como salteadores, «aunque no lo debían», porque, «por temor del tormento se levantaron testimonio falso», el juicio que hizo del caso fue que «murieron con muchas muestras de su salvación, que por aquel camino se la enderezó el Señor; a quien se den gracias por todo»» ${ }^{28}$.

A pesar de todo, lejos de lo que pudiera deducirse de la aplicación de castigos físicos y mutilaciones en las ejecuciones públicas, así como de la puesta en práctica de la cuestión de tormento en los interrogatorios que así lo requerían; a pesar de la comisión de errores judiciales, a veces incluso inducidos por la tortura, la justicia del Antiguo Régimen no era absolutamente insensible ni a la crudeza de los castigos corporales ni a sus propios errores.

${ }^{28}$ León (1628), ff. $357 \mathrm{v}^{\mathrm{o}}$ y $358 \mathrm{v}^{\mathrm{o}}-360$. 


\section{EL PERDÓN Y LA ENMIENDA DEL ERROR JUDICIAL}

Existían en la justicia del Antiguo Régimen instrumentos correctores del error y mitigadores de los castigos. Francisco Martín, muchacho de diecisiete años, condenado en Sevilla en 1586 a ser ahorcado y descuartizado, fue, sin embargo, retornado desde el cadalso a la cárcel, después de que fuera ahorcado su compañero Simón López. La plaza de San Francisco, donde se celebraban las ejecuciones estaba ese día «llena de gente esperando que ahorcasen al moçuelo aunque con muy mucha lástima de él porque no tenía culpa como se uerá». La responsabilidad criminal que la justicia achacaba a este muchacho se arraigaba en un crimen cometido a unas doce leguas de Sevilla, en un lugar llamado Villa Martiro:

«Aconteció lo que muchas veces en todas partes, que una señorita que estaua en posesión de doncella tubo un trabajo (como ellas suelen decir...) y para quando auía de deshaçerse él y parir tenía preuenida a la comadre que le buscasse un hombre que le fuesse a exponer la criatura a Bornos dos leguas de allí (que este es estilo que se tiene en estas embarcaciones o partos de trauiessa en los lugares cortos para no ser descubiertos los señores traviesos de lleuar las criaturas a los lugares más cercanos a donde tienen ay dado de pagarlo en la misma moneda) hizo pues la partera el concierto con este buen hombre Simón, que lleuasse la criatura a Bornos por seys reales. $»^{29}$

Cuando Simón salía del pueblo con la criatura, topó con Francisco Martín, al que se dirigió diciendo: «anda acá conmigo, lleuaremos a este niño a Bornos y partiremos lo que me dieren por lleuarlo». Los dos muchachos acordaron hacerlo, pero, cuando llegaron al Río Guadalete, Simón le dijo a Francisco que por qué no encomendaban la criatura a Dios y la enterraban a la vera del río, ahorrándose tener que ir hasta Bornos. Francisco se negó, puesto «que no abrá quien nos absuelva sino vamos al Padre Santo de Roma con todo esso». A pesar de ello, Simón «apretó la boquita y garganta a la criatura y lo despachó con cartas al cielo, [...] y enterrolo allí y boluiosse al pueblo con grande tristeza el Francisco». En los días siguientes hubo muchas lluvias. El río se desbordó y descubrió el cuerpo del niño, «y como viesen algunos del puesto aquel cuerpito muerto dieron noticia a la justicia». Practicadas las diligencias oportunas la comadrona confesó lo que había ocurrido y que ella había dado el niño a Simón López. Cuando le prendieron, él confesó de plano y dijo que con él había ido Francisco, pero que no tenía culpa. Prendieron también a ese muchacho. La sentencia fue consultada por el alcalde y condenaba a los dos a horca.

${ }^{29}$ León (1628), ff. 286-291 vo 
Llegado este punto, Pedro de León trató de evitar el ajusticiamiento del muchacho inocente. Conversó sobre el particular con el alguacil mayor Jerónimo de Montalvo, pero éste no encontraba medio de evitar que Francisco Martín fuera ajusticiado. El jesuita, al fin, le dijo que fueran ambos inculpados a la plaza de San Francisco, que allí Dios dispondría. Los reos fueron conducidos de la manera ordinaria a la plaza y horca. El auténtico responsable, Simón López, exculpó públicamente al mozuelo justo antes de ser ahorcado e insistió que así lo había dejado declarado en su confesión. El gentío era grande y mostraba compasión «de ver que uviesse de morir un muchacho tan sin culpa» ${ }^{30}$.

Ante la conmoción, el confesor se entretuvo con el muchacho. Caía la noche, ante la inquietud de alguacil, escribano y ministros de la justicia. El religioso no parecía acabar. Pretextaba que muy distinto era ejecutar a un hombre que a un muchacho, que éste necesitaba una preparación particular para morir. La plaza seguía llena de gente. Al cabo de un rato, la Justicia dio parte al jesuita de que, si tanta tarea había que hacer con el muchacho, que lo tornaran a la cárcel, que lo volverían al cadalso al día siguiente. A la mañana siguiente, los alcaldes de la Audiencia hicieron llamar al jesuita. Éste les dijo que el mozo no tenía aún dieciocho años, sino diecisiete, y que no había ayudado a consumar el crimen, sino precisamente tratado de evitar el infanticidio. No debía aplicársele pena ordinaria de muerte, sino una extraordinaria de destierro o galeras. Se llevaron los autos a Sevilla y se tuvieron en cuenta partes del proceso que en un primer momento no se habían considerado, particularmente la confesión del infanticida y las de algunos testigos. La sentencia fue reconsiderada. Se suspendió del oficio a los dos alcaldes más antiguos «que pareçe tuuieron los que más culpa» de que no se hubiera logrado justicia con la sentencia previa. Dos meses después del retorno a la cárcel, el muchacho fue sentenciado a «dos años de gentilhombre de galeras»»

Lo ocurrido a Francisco Martín, aún tratándose de un caso muy excepcional, da idea de todo un cúmulo de informaciones y negociaciones que tenían lugar a lo largo del proceso judicial y que, al igual que el procedimiento establecido por la justicia, también tenían como fin, quizá, el esclarecimiento de la verdad y la demostración de la inocencia del inculpado, o quizá la presión sobre la parte de la víctima, para lograr una escritura de perdón con la que poder tramitar un suplicatorio a la Corona. Se evitaba así que la justicia descargara todo el rigor implacable de la ley sobre los criminales. No siempre las circunstancias eran tan claras como las que actuaron como eximentes de gran parte de la responsabilidad criminal que se imputaba a Francisco Martín, pero había todo un cúmulo de factores que podían facilitar que el delincuente eludiera la pena capital. Podían darse casos como el del sargento de la Armada Juan Pérez Castillejo, hombre honrado procedente de

\footnotetext{
${ }^{30}$ León (1628), f. $288 \mathrm{v}^{0}$.

${ }^{31}$ León (1628), f. 291.
} 
Cazorla, que fue condenado en 1593 a muerte en garrote por su general de galeones, Francisco Coloma.

Castillejo había puesto fin a la vida de un piloto de la armada en medio de una bronca y defendiendo a su capitán. Los amigos del sargento pidieron a Pedro de León que solicitase al general de galeones la suspensión de la ejecución por veinte días. En ese término, ellos tratarían del perdón de la muerte con la viuda de la víctima. «Habían prometido todos los soldados dar para esto muy buena parte de sus sueldos, como lo hicieron muy honradamente». Transcurridos los veinte días de aplazamiento, el regimiento había logrado cuatrocientos ducados para la viu$\mathrm{da}^{32}$. Así se libró de la muerte en que estaba sentenciado Castillejo, quien posteriormente llegó a ser alférez en una compañía de infantería. Como se ve, las circunstancias de la muerte, en este caso en una bronca o «en sangre caliente», protegiendo a un superior, así como la solidaridad de un colectivo o grupo de referencia y, por supuesto, el perdón de la parte ofendida o la víctima del crimen, eran factores fundamentales para lograr eludir la pena capital.

En el caso del sargento Castillejo, fue la solidaridad desplegada por su entorno social, allende de los demás factores descritos, lo que resultó decisivo para librarse de la pena de muerte. En otros casos, era precisamente el entorno social del condenado el que había cooperado a que se produjera el crimen, y luego se había mostrado incapaz de compensar esto con la consecución de una suavización, remisión o conmutación de la condena. En 1615, un joven llamado Pedro Gutiérrez, natural de Utrera, fue ahorcado por matar a otro hombre de los de su cuadrilla, «de los que andan en el río de palanquín». Varios de sus compañeros le malmetían contra otro, sin que él hiciera caso de sus palabras. Dentro de la sociabilidad masculina de este grupo juvenil, rehuir el enfrentamiento también tenía consecuencias. Los compañeros de Pedro Gutiérrez llegaron a increparlo como «maricón» por eludir la bronca. Ese mismo día, el grupo fue a la casa de Gutiérrez y, en sus cercanías, fingieron tener una trifulca y acuchillarse entre ellos. Al oir el ruido y reconocer a sus compañeros, salió Pedro Gutiérrez de su casa «para ponerlos en paz», pero en el barullo acabó hiriendo a uno de ellos, que luego murió. Una vez apresado e iniciada la causa criminal contra Pedro, éste fue atormentado para que confesara su culpa y las circunstancias del delito. El resultado para este joven fue su muerte en la horca ${ }^{33}$.

Al igual que en el caso del sargento Castillejo, en Pedro Gutiérrez trató de lograr el perdón de la viuda, pero el entorno social que apoyaba a este muchacho fue incapaz de negociar bien y ajustar un precio conveniente con ella. El padre Pedro de León describió bien la situación cuando relataba que «antes que le dieran el tormento o cuestión de él, hacía la viuda el perdón por cuatrocientos ducados; y

\footnotetext{
${ }^{32}$ León (1628), ff. 312-312 v .

${ }^{33}$ León (1628), ff. 375-376.
} 
no le daban más de trescientos». El asunto se quedó entonces sin resolver por una diferencia de ajuste de cien ducados. Si se hubiera logrado el ajuste con la parte de la víctima, el desenlace podía haber quedado en que al involuntario homicida «le echaran por la puerta afuera o con un destierro». Sin embargo, luego, «cuando supo la dicha viuda que había confesado él mismo en la cuestión de tormento, que él lo había muerto, no quiso perdonarlo por ningún dinero». Así llegó la sentencia y ejecución del joven. Después de la confesión realizada por Pedro Gutiérrez en el potro, parece que toda negociación era ya inútil. La responsabilidad criminal, que hasta ese momento la viuda podía contemplar como diluida dentro del grupo de jóvenes que se había visto envuelto en la trifulca, luego de la confesión autoinculpatoria arrancada a Pedro Gutiérrez por medio de la tortura, tenía ya un nombre y apellidos. Para lograr eludir la pena capital, por lo tanto, además de todos los factores anteriormente indicados, parece que intervenía otro importantísimo: el momento en que debía fenecer la negociación, la oportunidad para intuir cuándo debía cerrarse el pacto entre partes.

En otros casos, los testimonios manifestados por los protagonistas del crimen o su entorno también afloraban emociones que tenían un fuerte sustrato cultural, y que evidenciaban una percepción social de la justicia que no fenecía con la propia decisión del juez, expresada a través de su sentencia, o incluso con la ejecución de ésta. El padre Pedro de León narró en 1615 un episodio ocurrido quizá algo más de una década antes, en el que un hombre sevillano, inculpado y confeso en cuestión de tormento por la muerte de un clérigo cerca de la puerta de Triana, siendo inocente del delito, ya en el cadalso pidió palabra para dirigirse al gentío que asistía a su ejecución. Logrando esta gracia al reo, éste emplazó al escribano Martín Morales «que está presente, para que dentro de veinte días vaya a dar cuenta a Dios conmigo de este agravio que me ha hecho solicitando mi muerte». Añadió el reo, refiriéndose al crimen, que él no había hecho «esta maldad». El jesuita se le acercó y, también ante el público, le dijo que mirase que esas palabras nacían de su deseo de venganza y que desear la muerte del prójimo es pecado mortal. Tras la intervención del misionero, al parecer, el condenado se sosegó y pidió perdón al escribano y todos los circunstantes «del mal ejemplo que les había dado con aquellas palabras». Lo cierto es que el escribano murió súbitamente unos veinte días después de este suceso, mientras oía misa, pero sin ocasión de confesar sus pecados, según relató Pedro de León ${ }^{34}$.

Es evidente que, en este último caso, el inculpado no había logrado el perdón de la parte ofendida y que la sentencia que lo condenó a muerte se apoyaba fundamentalmente en una falsa autoinculpación del reo que le había sido arrancada por fuerza en el potro de tortura. En circunstancias semejantes, otros condenados

\footnotetext{
${ }^{34}$ «Quiera Él haberle cogido en buen estado, que para escribano de la justicia, que no suelen ser los más justos del mundo, terrible prisa fue caerse allí muerto sin decir Jesús váleme». León (1628), ff. $376 \mathrm{v}^{\mathrm{o}}-378 \mathrm{v}^{\mathrm{o}}$.
} 
tuvieron mejor fortuna. Alguno incluso logró eludir la ejecución de la pena capital cuando ya se encontraba en el patíbulo. Todo un cúmulo de factores podía propiciar el perdón de la parte ofendida, incluso por la presión social de la aclamación popular al reo en el mismo lugar de ejecución. Lograr el perdón de la parte de la víctima era un factor condicionante de la decisión favorable al indulto que podía adoptar la Corona ante cada expediente de suplicatorio de gracia. El perdón de la parte de la víctima era, pues imprescindible, para eludir la pena capital. El vigor de este principio tenía unas sólidas bases en la época medieval. Así, para explicar su significado es preciso analizar sus raíces en la práctica legítima de la venganza como instrumento retributivo del daño infligido a la parte de la víctima. Esto conformaba una suerte de justicia privada reconocida por la ley o la costumbre en las sociedades occidentales de la última época medieval.

Hace décadas que Tomás y Valiente enfatizó la importancia y vigencia social de la venganza privada en la sociedad castellana de la época moderna ${ }^{35}$. Hoy sabemos que exageraba al afirmar, refiriéndose a las injurias o violencia verbal, que «casi nunca se acudía a la justicia para denunciar el delito» y que, por lo tanto, «lo más frecuente era la venganza privada» ${ }^{36}$. Sin embargo, es cierto que múltiples suertes de pendencias reflejaban una presencia veraz de la venganza en las sociedades rurales y urbanas de la Castilla Moderna ${ }^{37}$.

En la época medieval, diversas formas de enfrentamiento, más o menos ritualizado, que se expresaban mediante la lid o el riepto y el duelo, articulaban la venganza privada, pero la conferían el significado de ordalía, es decir, de prueba auspiciada por Dios. En las leyes de Partidas, del Fuero Real o de 1348, se trató, no obstante, de minorar las connotaciones ordálicas de estas prácticas y abundar en las propiamente jurídicas ${ }^{38}$. El riepto entre nobles cada vez más claramente debía ser controlado por los reyes, quienes lo concedían o no, y quienes presidían o dirigían la lid. De algún modo, esta práctica fue desapareciendo en la Castilla del siglo xv para difuminarse dentro de nociones más generales, amplias y flexibles del duelo o desafíos entre nobles o entre villanos, contra los que ya lanzaban invectivas los Reyes Católicos en los años ochenta del siglo xv, convirtiendo estos enfrentamientos privados, no el riepto, en delito condenado. Esta invectiva fue reforzada por diversas disposiciones canónicas a lo largo de los siglos XVI y XVII sobre la base de las condenas tridentinas ${ }^{39}$. A pesar de todo, el duelo, cada vez más claramente un desafío privado

35 Tomás y Valiente (1969), pp. 46 ss.

${ }^{36}$ Los estudios de Testón (1985), Mantecón (1997 y 1999, pp. 203-223), Alloza (2000), Barahona (2003) e Iglesias (2004) han permitido comprobarlo en los casos de Extremadura, Cantabria, Madrid, el País Vasco y Galicia.

${ }^{37}$ Mantecón (2004); Iglesias (2004).

38 Tomás y Valiente (1969), pp. 48-50.

${ }^{39}$ Tomás y Valiente (1969, pp. 56-57 y 61-62) ha ofrecido ejemplos de celebraciones de riepto, a pesar de que las formas cambiaran frente a las más tradicionales, en la Castilla de las primeras décadas del siglo xvi, con la mediación del emperador. 
sin otorgamiento regio pero con «la muda complicidad real» ${ }^{40}$, desafiando las prohibiciones y condenas legales, tuvo una vigencia importante en la sociedad castellana de la época moderna. En el siglo Xviı era un fenómeno que, lejos de asumir una significación única, estuvo cargado de connotaciones y, en la práctica, distaba mucho de ser patrimonio de un grupo o una categoría social determinada, de tener una significación simple como regresión hacia formas primitivas de venganza, o de parapetarse solamente en pervivencias de la tradición del riepto o en justificaciones morales sobre la legítima defensa ${ }^{41}$.

El duelo privado o desafío no fue patrimonio del estamento nobiliario o de los jóvenes integrados en la milicia. En Castilla, al igual que ocurría por ejemplo en Amsterdam $^{42}$ y en contraste con las interpretaciones tradicionales sostenidas por parte de la historiografía europea sobre el duelo ${ }^{43}$, a lo largo del siglo XVII las clases populares participaron en esta práctica para dirimir conflictos de distinta naturaleza, lógica y significación ${ }^{44}$. Todo parece indicar que esta práctica tampoco fue exactamente una importación cultural procedente de la apropiación realizada por las tropas españolas a su retorno de las guerras de Italia, sino que existía toda una tradición que amparaba la presencia del desafío privado entre los castellanos, preferentemente nobles, siempre que fuera una expresión de los valores morales. El avance y extensión social en la Europa Moderna del «proceso de civilización» descrito por Norbert Elias ${ }^{45}$, así como la progresión de la «revolución jurídica» que observaron Parker y Lenman ligada al avance del derecho penal ${ }^{46}$, la mejor definición de los ilegalismos y el desarrollo de la maquinaria institucional para judicializar los conflictos de todo género entre los europeos de la época preindustrial, debieran haber contribuido a reducir la venganza, que se expresaba a través de pendencias entre parentelas, facciones o clientelas, a las reglas del duelo privado o desafío que, por otro lado, tendría el efecto de convertir un conflicto entre grupos en un enfrentamiento entre individuos.

En la Castilla Moderna el desafío o duelo privado convivió, sin rivalizar, con la pendencia o lucha entre parentelas o facciones. Aunque ésta tuvo mayor presencia en el mundo rural que en el urbano, no dejó de manifestarse en las villas y ciudades castellanas, al menos hasta la segunda mitad del siglo xvII. De igual manera,

\footnotetext{
${ }^{40}$ Como indicó Tomás y Valiente (1969), p. 63.

${ }^{41}$ Un análisis sobre este particular, con evidencias empíricas de las variadas significaciones de los desafíos en la sociedad castellana del siglo xvir, puede leerse en Mantecón (2004, pp. 195-228). Tomás y Valiente (1969, pp. 64-67) explicaba esa pérdida de control regio del duelo como una regresión que permitía aflorar «formas primitivas de venganza».

${ }^{42}$ Spierenburg (1998a).

43 Billaçois (1986) y Kiernan (1988).

44 Mantecón (2004).

45 Elias (1987).

${ }^{46}$ Lenman y Parker (1980), pp. 11-48.
} 
el desafío, al parecer un fenómeno más urbano que rural, también tuvo concreciones rurales hasta el declive de la práctica a partir de la segunda mitad del siglo XVIII. Ya en el siglo xIX, justo cuando el movimiento romántico trataba de rescatar y reinventar códigos de honor, arcaicos valores nobles y redescubría la tradición el duelo, éste recobraba un renovado interés literario, que contrastaba con el desgaste de la práctica. Quizá fuera entonces cuando se asentó el modelo explicativo que nos han trasladado las investigaciones de Billaçois y Kiernan ${ }^{47}$. Éstas asociaban la práctica del duelo a un estamento, el nobiliario, y a una interpretación del desafío privado como expresión de valores relacionados con una idea de honor, deudora en gran medida del romanticismo. La realidad, sin embargo, había sido mucho más compleja que todo esto.

Volviendo a la materia que ahora nos ocupa, el procedimiento penal castellano debía responder a la necesidad de dar una satisfacción dual por parte del reo para restaurar la paz pública y evitar que aflorara la justicia privada en cualquiera de sus manifestaciones. Por un lado, había que satisfacer la parte de la víctima y, por otro lado, había que reparar la vindicta publica. Si es cierto que el monarca era el único con capacidad para conmutar las sentencias y remitir o mitigar las mismas total o parcialmente, también lo es que sólo podía hacerlo si la parte ofendida se consideraba satisfecha, y eso se demostraba por medio de una escritura de perdón que incluyera también el apartamiento de la causa contra el delincuente. Además, en ese mismo o en otro documento, la parte de la víctima podía expresar su voluntad de sumarse al suplicatorio de perdón del agresor ante la Corona. Como se ha tenido ocasión de comprobar, este esquema abría todo un marco de negociaciones entre el criminal y la justicia a través del procedimiento penal establecido, a la vez que otro abanico de transacciones y composiciones entre la parte agresora y la ofendida, fuera de los juzgados. La justicia privada y la justicia institucionalmente ejercida actuaban a la vez y se interferían y afectaban mutuamente en distintos momentos de la resolución del conflicto.

Controlar los tiempos y los ritmos en las negociaciones entre las partes era una cualidad esencial para lograr un desenlace satisfactorio. Alguno de los ejemplos estudiados permite comprobarlo. A veces, el perdón de la parte ofendida, que afectaba decisivamente a todo el proceso, se obtenía justo en el último momento. Francisco de Triana, por ejemplo, logró salvar su vida el mismo día en que fue conducido a la horca que le aguardaba en la plaza de San Francisco de Sevilla, en 1583. Había tenido una riña con otro joven en el altozano de Triana, «en la cual refriega lo mató y se entró en la iglesia de San Jorge que era la del Santo Oficio». A la sazón, pasaba por allí uno de los cuatro alcaldes de la audiencia y, conociendo el incidente, entró en la iglesia, llevó a la cárcel al homicida, y en tres días lo condenó a horca. Parecía haber demasiada prisa para ajusticiarle y, por eso, el

\footnotetext{
${ }^{47}$ Billaçois (1986) y Kiernan (1988).
} 
confesor Pedro de León, al que se había encargado la cura espiritual del reo, alargó todo lo que pudo la confesión hasta que los carceleros acabaron por exhortarle que lo dejara, que era hora de ir a ajusticiar, al reo. En este caso, el jesuita fracasó con el mismo ardid que repitió tres años después logrando salvar la vida de Francisco Martín, ya en el mismo cadalso. No obstante, intuyendo el fracaso, el padre León acudió entonces a la casa del regente, superior de los alcaldes de la audiencia. Cuando estaba relatándole lo ocurrido y él asegurando que no sería así, se llegó al lugar el alcalde de la cárcel para dar aviso al jesuita que el reo estaba ya a la puerta de la cárcel sobre el jumento y esperándole junto con el alguacil y el escribano para iniciar la marcha al lugar de ejecución. El jesuita hizo ver al regente que su relato era cierto, y salió de la casa hacia el lugar donde se iniciaba la comitiva de penados.

A lo largo de todo el camino hacia el patíbulo, el reo gritaba y se lamentaba porque no le habían dejado comulgar, conmoviendo al remolino de gentío que se agolpaba en Triana por ser Viernes del Espíritu Santo, «que suele ir mucha gente» al barrio. Ante el espectáculo, la gente pedía a la viuda de la víctima que diera el perdón al reo. Entre el gentío de solicitantes se encontraba un secretario del Santo Oficio que se llama Ericeno, y con él dos jesuitas y otros dos dominicos que ofrecían doscientos ducados a la viuda para que concediera su perdón al condenado. Mientras, Pedro de León acababa de confesarle, apremiado por los oficiales de la Justicia. No podía retenerlos más. Según el juicio del jesuita, habría tenido más influencia de haber sido la justicia ordinaria y no la de la audiencia la que dictara sentencia. Pusieron, al fin, la soga al cuello del homicida, mientras él seguía gritando y pidiendo favor a los miembros del Santo Oficio, de cuya iglesia le habían sacado. El padre León se entretenía con él más que con los demás condenados. El verdugo le hizo señas para que abandonara el patíbulo y trató de quitar al reo una cruz que le había dado el jesuita. El alguacil y el secretario de la audiencia decían al verdugo que acabase de una vez, cuando, entre la multitud, se comenzó a oir a gritos la palabra perdón, dando a entender que la viuda de la víctima había accedido a las súplicas del gentío.

En ese momento, Pedro de León corrió a abrazarse al reo para que el verdugo no lo ajusticiase ${ }^{48}$. El alguacil, anteriormente, había estado preso más de un año «porque le achacauan que auía muerto a su propia muger». El misionero aprovechó esta circunstancia y alzó la voz, exclamando al público que debían esperar al menos una hora por el reo, pues «otros delitos ai más o mejor que este y se an disimulado y pasado entre renglones y no se han hecho tantas bramuras y alharacas; todavía está la sangre deste delito fresco y la de otros que ay más verdes está enjuta y olvidada». El alguacil bajó la cabeza. Los frailes fueron a explicar la situación a la Audiencia de la ciudad, con el compromiso de las autoridades de

\footnotetext{
${ }^{48}$ León (1628), ff. 268-268 vo .
} 
que no ajusticiarían al reo hasta su regreso. La muchedumbre pedía que se devolviese el preso a la cárcel, ya que había perdón de la parte ofendida y que éste era por escrito. Cumplidas las formalidades, el preso fue bajado de la horca, volvió a la cárcel, y de allí a la iglesia de donde lo habían sacado, "puesto que no auía sido a traición la muerte sino riñendo de bueno a bueno» ${ }^{49}$.

Varios factores coadyuvaban para que este muchacho pudiera eludir la pena capital y lograr una conmutación de la sentencia dada por la Audiencia sevillana. Favorecía la consecución del indulto el hecho de ser fortuita la muerte que provocó; gozar de un respaldo social en Triana; haberse acogido al refugio de santuario en un primer momento, de donde había sido sacado de una forma irregular por la Justicia y, por supuesto, el gozar, después del episodio descrito, del perdón de la parte ofendida, que era imprescindible para que la Corona decidiera conmutar las sentencias dadas por tribunales que actuaban en su nombre. Eventualmente, pudieron ser decisivos factores como la manifiesta inocencia del delincuente, a pesar de la sentencia, y la conmoción que la ejecución de la misma pudiera provocar en la población urbana de Sevilla, con particularidad en el barrio de Triana.

De bueno a bueno también había sido el enfrentamiento entre los tenderos sevillanos Sebastián Escobar y Diego de Almanza. La riña fue motivada porque el primero había declarado ante el teniente mayor de la ciudad que Almanza había tenido pendencias, broncas y discusiones con otros. Esto generó tensión entre Escobar y Almanza. A pesar de que los habían hecho «muy amigos», a principios de septiembre de 1629 tuvieron una nueva discusión, se amenazaron, y cruzaron sus espadas. En medio de la trifulca, no pudo saberse quién fue el que dio una estocada mortal a Escobar. Ese año, la viuda y el curador de su hijo menor, previa «información de utilidad» que manifestó la fragilidad económica de Almanza, decidieron apartarse de la querella contra su vecino, para que se le pudiera conmutar el castigo que se le echara por la culpa que tuviera en la muerte de Escobar. A Diego de Almanza el indulto le costó 800 reales, aplicados a la Cámara de Castilla (500 rs.) y al oficial de la misma que tramitó el suplicatorio (300 rs.) $)^{50}$. En este caso, el conocimiento personal del agresor, la vecindad entre las partes, la frecuencia de trato, la fragilidad económica y las circunstancias en que se produjo el crimen -en medio de una bronca- fueron factores que favorecieron el perdón de la parte ofendida y, posteriormente, la remisión de condena.

En todo caso, para que se dieran desenlaces como éste, con resultado de indulto y conmutación de sentencia, debía existir todo un marco institucional que propiciara la canalización de una práctica para la que sólo el rey tenía una potestad legítima. La gracia real se expresaba bien a través de los conocidos Perdones de Viernes Santo, bien en conmemoraciones eventuales que la permitieran. Con

\footnotetext{
${ }^{49}$ León (1628), ff. $268 \mathrm{v}^{\mathrm{o}}-270 \mathrm{v}^{0}$.

${ }^{50}$ AGS (Archivo General de Simancas), Cámara de Castilla, leg. 1778, doc. 3 ff. 4-9.
} 
ocasión de la celebración de acontecimientos que afectaban positivamente a la familia real o a la política desarrollada por la Corona, se ofrecían nuevas ocasiones para el indulto de criminales. Otra opción pasaba por elevar un suplicatorio ante la Cámara de Castilla para que el caso fuera considerado como uno al sacar. Se pedía que se tasara la parte de la sentencia para la que el reo suplicaba el perdón, a cambio de una compensación pecuniaria, de cuyos beneficios podían participar también los funcionarios de la Cámara que hubieran llevado el caso ante la consideración del tribunal. Así fue tramitado el expediente sobre la culpa del tendero hispalense Diego de Almanza, ya mencionado.

El perdón de la parte ofendida era imprescindible en todo caso, como se ha dicho, para lograr el indulto. Podía llegar por considerar la parte de la víctima que en la comisión del crimen no había habido «mala fe», que fue fruto de acaloramiento y de falta de autocontrol, o consecuencia de la inmadurez de los protagonistas. También podía darse el caso de que no hubiera demandantes, bien por no haberse personado familiares directos de la víctima en la causa o bien porque no se conocieran parientes, tratándose de forasteros o extranjeros. No sólo la inmadurez, apasionamiento e intención del agresor para cometer el delito podía hacer que la parte de la víctima propiciara un perdón privado y se apartara de la demanda; la condición social del agresor y su disponibilidad económica, así como su relación de amistad o enemistad, vecindad, paisanaje o parentesco, influían en la decisión que tomara la familia de la víctima. La extrema pobreza del agresor, unida a las circunstancias en que se hubiera provocado la muerte, eran factores que podían influir positivamente en la parte de la víctima para lograr su apartamiento de la querella, perdonar y propiciar el futuro indulto del delincuente. También la familia, parentela, clientela, comunidad, corporación y grupo étnico o cultural en que se integraba el inculpado eran factores que le otorgaban diferenciadas oportunidades para lograr el indulto.

En la capital andaluza, por ejemplo, el 17 de noviembre de 1615 fue asaeteado en el camino de San Lázaro un gitano llamado Baltasar Cuadrado. Formaba parte de una cuadrilla de salteadores de caminos en el itinerario a Carmona. La gavilla era formada por cuatro bandidos, dos gitanos y otros dos «cristianos viejos», uno de ellos un alguacil llamado Alonso Sánchez, mencionado por el gitano Baltasar Cuadrado cuando se le aplicó el tormento en el potro. Había sido precisamente el alguacil «el que les había metido a él y a los otros en la andanza». El gitano no negó este extremo ya en la cárcel, a pesar de las presiones para que se desdijese y absolviese al alguacil. Tampoco se desdijo en el último momento, justo antes de ser ajusticiado. Según el padre Pedro de León,

«con la muerte del gitano y su confesión a la hora de la muerte, ratificándose en la primera confesión, no dejará el alguacil de correr algún mal riesgo, que antes y por menos, le acabarán de dar el tormento, y Dios le ayu- 
de. Que yo pienso que el gitano se salvó y escapó de la cárcel del infierno y el alguacil sobredicho se escapará de la de la Hermandad, porque tiene muchos valedores y es de gente muy honrada y el pobre tiene dos o tres hijas grandes ya para casar y todos les tienen mucha lástima a ellas y a su madre, porque si muriese asaeteado perderían mucha honra y nadie se casaría con ellas» ${ }^{51}$.

El alguacil no se libró del prendimiento y el tormento, pero tuvo vigor para negar todos los cargos en el potro. Su sentencia no fue de muerte, sino de destierro. Su condición y entorno social de «gente honrada», sus «valedores» y oficio, además de su fortaleza física y de ánimo para soportar el tormento, debieron influir al juez para mitigar la dureza del castigo que le correspondía.

Finalmente, lograr el perdón de la parte ofendida también podía formar parte de una negociación entre la parte del agresor y la de la víctima para tasar el daño causado y garantizar una reparación que permitiera restablecer el equilibrio de las relaciones entre las partes y dentro de su entorno social. Eso era esencial cuando los lazos entre el agresor y su víctima eran muy estrechos o cuando ambos compartín vecindad y proximidad en el trato de cada día. En este supuesto, la negociación entre las partes también estaba sujeta a presiones que se ejercían sobre la parte de la víctima, bien por mediadores señalados por las partes bajo título de «hombres buenos» o bien porque la parte de la víctima formaba parte de la misma parentela que la del agresor, y la fragilidad en que quedaba después del crimen cometido por el agresor era tan grande que no podía prescindir de un acuerdo capaz de garantizar la suficiencia económica de la comunidad doméstica y el mantenimiento de la solidaridad familiar y vecinal en el futuro.

\section{CONCLUSIONES}

El esquema foucaultiano enmarcaba una divisoria entre una justicia represiva, propia del Antiguo Régimen, y una utilitaria, característica de las sociedades liberales. Un enfoque de esta naturaleza necesariamente contiene una simplificación poco realista, puesto que los sistemas judiciales modernos también tratan de represar, contener o reprimir el crimen, y los del Antiguo Régimen no buscaban necesariamente, y mucho menos siempre, sino muy excepcionalmente, la eliminación del criminal y el castigo del cuerpo de los delincuentes. Después del estudio realizado sobre la economía del castigo y el perdón en la sociedad sevillana de tiempos de Cervantes, parece evidente que no todos los condenados a pena de muerte fueron ejecutados, sino que cabían opciones para evitar este desenlace

${ }^{51}$ León (1628), ff. 381-383. 
incluso cuando todo parecía indicar que el ajusticiamiento se iba a producir inexorablemente.

La justicia del Antiguo Régimen trataba desigualmente a los condenados según su rango, estado, género y etnia. Podía expresarse con extremada y descarnada dureza según las circunstancias aconsejaran, pero no era una justicia necesariamente más despiadada que la que emergía en el seno de las sociedades liberales; sencillamente, era distinta. Cierto que mutilaba, descuartizada, mortificaba el cuerpo de algunos criminales, y que exhibía estos fragmentos anatómicos en lugares públicos, en las puertas que daban acceso a las ciudades o en los promontorios de los puertos comerciales más importantes, pero en esto también existía una dimensión utilitaria, preventiva del delito e inhibidora del crimen. El mismo sentido tenía la escenografía que componían los discursos, arrepentimientos y sufrimientos de los condenados en público. En Sevilla no se llegaron en esas fechas a imprimir los last dying speeches de los condenados, como ocurrió en Londres, de forma creciente incluso a medida que avanzaba el siglo xvIII; sin embargo, en la capital andaluza los reos podían exclamar en público sus últimas palabras cuando estaban ya colocados en el patíbulo, ante la horca y con la asistencia de algunos misioneros que acompañaban su cortejo desde la prisión hasta el lugar de ejecución. Todo esto tenía un efecto instructivo para la muchedumbre y para los propios oficiales de la justicia. Éstos fueron ocasionalmente el blanco de la desesperación de reos, particularmente de aquellos condenados injustamente tratados o víctimas de error judicial que no se resignaban a aceptar el castigo.

Michel Foucault quedó fuertemente impresionado, como ocurre con cualquier hombre de nuestro tiempo, cuando leyó la descripción del ritual que se puso en marcha para ejecutar a Robert Damiens. El desarrollo de este ajusticiamiento o de cualquiera de los que han sido descritos en estas páginas no debió impresionar menos que al filósofo francés al gentío que se agolpaba en las calles por las que pasaban los cortejos de los condenados, y a las muchedumbres que se apiñaban en las plazas de ejecución. La pena capital, aunque regularmente aplicada en Sevilla, como en todas las grandes ciudades de la Europa Moderna, sin embargo no era la norma del desenlace de un proceso criminal, sino la excepción, incluso en el caso de delitos que legalmente merecían ese castigo. Pero la justicia encontraba medios para hacer visible cotidianamente a las gentes también su lado más riguroso. Seguro que las muchas manos, brazos, piernas o cabezas de ejecutados que se colgaran regularmente en las puertas de las ciudades, no pasaban inadvertidas a cuantos circulaban cada día por estos parajes urbanos. Para eso precisamente se colocaban. No obstante, la Justicia era mucho más que eso en la Europa Moderna. La autoridad del rey, y su prudencia paternal para decidir sobre el castigo y el perdón, ejercida a través de todo un conjunto de instituciones, derivaban de la oeconomica del arte del buen gobierno de la casa. 
En el último extremo de la cadena judicial, con la postrera palabra sobre el asunto, la Corona fallaba cada expediente de súplica de forma individualizada, desestimándolo o canalizándolo hacia cualquiera de las modalidades de indulto que han sido ya indicadas. La justicia se concretaba a lo largo de todo un largo proceso, en la evolución del caso dentro de las diferentes salas y tribunales hasta los Consejos. Se expresaba de forma oficial, dentro de los juzgados, y extraoficialmente, entre las partes, fuera de los tribunales. Su manifestación era el resultado último con que se superaba el conflicto, ya fuera en el patíbulo o a través de una composición entre partes y una conmutación de la sentencia. El desenlace último de cada caso era fruto tanto de la acción institucional como de la capacidad de las partes para negociar y aprovechar en su beneficio cada una de las ocasiones que ofrecía, por un lado, el procedimiento penal y, por otro lado, la costumbre y la presión social.

Todo el esquema trazado describía una economía del perdón que era contrapunto de la del castigo, y ambas eran ingredientes indisolubles de una justicia que se manifestaba como híbrida -oficial, pero también popular- en estos periodos de la Edad Moderna. Una justicia en que intervenían, y a la que influían, las partes en litigio y los entornos sociales particulares de la víctima y el agresor. Por eso permitía integrar tradicionales concepciones privadas de la justicia. Éstas manifestaban la presencia de un vestigio retributivo o remunerativo en cada acción de justicia, pues debía reparar el daño causado a la parte de la víctima, además de la vindicta publica. Por supuesto, también los propios oficiales de justicia dejaban su sello en el desenlace de los procesos, a veces incluso provocando o propiciando errores judiciales, como ha tenido ocasión de comprobarse en alguno de los ejemplos analizados.

Igualmente, afectaba al resultado último de la acción judicial, a la ejecutividad de las sentencias, la participación de otros agentes, especialmente los que actuaban como mediadores entre las partes. Se trataba de intermediarios que no estaban dentro del marco institucional genuino de la administración de justicia. Eran agentes como el padre Pedro de León, misioneros, confesores de criminales, predicadores locales y, por supuesto, el conjunto de la sociedad urbana. Ésta se expresaba a través de la actitud que adoptara el gentío que acudía a las ejecuciones y que tuvo, en ocasiones, un protagonismo fundamental para evitar la ejecución de reos singulares y corregir errores judiciales manifiestos. Son estas materias importantes para caracterizar el funcionamiento de la justicia del Antiguo Régimen, pues afectaban decisivamente a la ejecutividad de las sentencias condenatorias. Aún es un reto de la historiografía europea el estudio de esta última cuestión, puesto que no sabemos ciertamente las proporciones de la relación entre sentenciados y ejecutados. Los historiadores del crimen no dudamos en reconocer la existencia de una cifra oscura en la documentación judicial que impide que, aún en nuestros días, conozcamos exactamente el impacto del crimen en las sociedades, puesto 
que el crimen registrado no coincide con el cometido. Existe también una cifra negra, aún más oscura que la anterior, que nos impide conocer el impacto real de las ejecuciones de criminales en la Europa del Antiguo Régimen. Esto es, principalmente, lo que ha alimentado la generalización de apreciaciones superficiales sobre la base de tópicos o apoyadas en muy liviano soporte empírico.

Todas estas características de la Justicia del Antiguo Régimen, que el análisis del caso sevillano me ha permitido sintetizar, ponen de manifiesto que la imagen trazada por Foucault hace ya treinta años no hacía justicia a la complejidad de la realidad que conocieron las gentes que vivieron en las ciudades de la Europa Moderna. El universo social que inspiró al Manco de Lepanto y que el escritor retrató de forma tan genial como escueta en su Rinconete y Cortadillo ofrece, como se ha podido comprobar, valiosa información para conocer el auténtico alcance de los castigos torturantes en una sociedad urbana del Antiguo Régimen, la más dinámica de la España tempranomoderna, y muestra que la terrible ejecución que sufrió Robert Damiens en 1757 no era la regla, sino la excepción, al menos en la Sevilla que conocía Cervantes.

\section{BIBLIOGRAFÍA}

Alloza, A. (2000): La vara quebrada de la justicia. Un estudio histórico sobre la delincuencia madrileña entre los siglos XVI y XVIII. Madrid: Catarata.

Barahona, R. (2003): Sex Crimes, Honour and the Law in Early Modern Spain. Vizcaya, 1528-1735. Toronto: University of Toronto Press.

BIllaçois, F. (1986): Le duel dans la société française, XVI ${ }^{e}-X V I I^{e}$ sièclès. Essai de psychosociologie historique. París: Editions de l'Ecole des Hautes Etudes en Sciences Sociales.

CARRASCO, R. (1985) : Inquisición y represión sexual en Valencia. Historia de los sodomitas (1565-1785). Barcelona: Laertes.

Cervantes, M. DE (1997) [1613]: «Rinconete y Cortadillo», en Novelas ejemplares. Madrid: Espasa Calpe, Colección Austral, pp. 175-240.

Defoe, D. (1728): Augusta Triumphans: or the way of making London the most flourishing city of the universe. Frist, by establishing a university where gentlemen may have academical education under the eye of their friends. II, to prevent much murder, \&c. by an hospital for foundlings,[...]concluding with an effectual method to prevent street robberies; and a letter to Coll. Robinson on account of the orphans tax. Londres: J. Roberts.

Elias, N. (1987): El proceso de civilización. Madrid: Fondo de Cultura Económica.

FIELDING, H. (1751): A enquiry into the causes of the late increase of robbers, \&c... with some proposals for remedying this growing evil. Dublín: G. Faulkner.

Forner, J. P. (1990) [1792]: Discurso sobre la tortura. Edición de Santiago Mollfulleda. Barcelona: Crítica.

Foucault, M. (1975): Surveiller et punir. Naissance de la prison. París: Gallimard. 
IgLESIAS, R. (2004) : «Las quiebras del orden cotidiano : comportamientos criminales en la sociedad gallega de fines del Antiguo Régimen». Santiago de Compostela : Universidad de Santiago de Compostela. Tesis Doctoral inédita.

Kiernan, V. G. (1988): The Duel in Euroepan History. Honour and the Reign of Aristocracy. Oxford: Oxford University Press.

LARDIZÁBAl y URIBE, M. (1782): Discurso sobre las penas, contrahído a las leyes criminales de España para facilitar su reforma, por Don Manuel Lardizábal y Uribe, del Consejo de Su Majestad, su alcalde del crimen y de hijosdalgo de la Real Chancillería de Granada. Madrid: Joaquín Ibarra.

Laslett, P. (1965): The World We Have Lost. Londres: Methuen.

- (1983): The World We Have Lost: Further Explored. Londres: Methuen.

Lenman, B., y Parker, G. (1980): «The State, the Community and the Criminal Law in Early Modern Europe», en B. Lenman, G. Parker, G. y V. A. C. Gatrell (eds.), Crime and the Law. The Social History of Crime in Western Europe since 1500. Londres: London Publications Limited, pp. 11-48.

León, P. DE (1628): Compendio de las industrias en los ministerios de la Compañía de Jesús con que práticamente se demuestra el buen acierto en ellos. Dispuesto por el Padre Pedro de León de la misma Compañía y por orden de los superiores.1628. Manuscrito 573. Segunda parte. Apéndice 1. (Biblioteca Unversitaria de Salamanca). Se ha cotejado esta versión manuscrita con la edición preparada por Pedro Herrera Puga (1981): Grandeza y miseria en Andalucía. Testimonio de una encrucijada histórica (1578-1616). Granada: Facultad de Teología.

Linebaugh, P. (1993): The London Hanged. Crime and Civil Society in the Eighteenth Century. Londres: Penguin Books.

Mandeville, B. (1725): An enquiry into the causes of the frequent executions at Tyburn, and a proposal for some regulations concerning felons in prison [...] To which is added, a discourse on transportation and a method to render that punishment more effectual. Londres: J. Roberts.

Mantecón, T. A. (1997): Conflictividad y disciplinamiento social en la Cantabria rural del Antiguo Régimen. Santander: Universidad de Cantabria/Fundación Botín.

- (1999): «Honour and Everyday Life in the Spanish Old Regime». Cap. 9 de H. Schilling (coord.), Institutionen, Instrumente und Akteure Sozialer Kontrolle und Disziplinierung im Frühneuzeitlichen Europa. Frankfurt a. M.: Klostermann.

- (2004): «Lances de cuchilladas y justicia en práctica en la Castilla del siglo XVII», en J. A. Munita (ed.): Conflicto, violencia y criminalidad en Europa y América. Bilbao: Servicio Editorial de la Universidad del País Vasco, pp. 195-228.

- (próximo): «Las culturas sodomitas en la Sevilla de Cervantes», en Homenaje a Don Antonio Domínguez Ortiz. Granada: Servicio de Publicaciones de la Universidad de Granada.

SharPe, J. (1985): «Last Dying Speeches: Religión, Ideology and Public Execution in 17thCentury England». Past and Present 107, pp. 144-167.

- (2005): Dick Turpin. The Myth of the English Highwayman. Londres: Profile Books.

Spierenburg, P. (1991a): The Broken Spell. A Cultural and Anthropological History of Preindustrial Europe. New Brunswick: Rutgers University Press.

- (1991b): The Prison Experience: Disciplinary Institutions and Their Inmates in Early Modern Europe. New Brunswick: Rutgers University Press. 
— (1998a): «Violencia, castigo, el cuerpo y el honor: una reevaluación», en V. Weiler (comp.), Figuraciones en proceso. Santafé de Bogotá: Fundación Social, pp. 116-151.

- (1998b): «Close to the edge: criminals and marginals in Dutch cities». Eighteenth-Century Studies 31 ( 3), pp. 335-359.

Testón, I. (1985): Amor, sexo y matrimonio en Extremadura. Badajoz: Universitas.

Tomás y VAliente, F. (1969): El derecho penal de la monarquía absoluta. Madrid: Tecnos. 
